\section{Pacific Northwest}

National Laboratory

Operated by Battelle for the

U.S. Department of Energy

\title{
Interim Report on Uranium Metal Segregation Testing
}

\author{
A. J. Schmidt \\ M. R. Elmore
}

April 2004

Prepared for the U.S. Department of Energy under Contract DE-AC06-76RL01830 


\title{
DISCLAIMER
}

This report was prepared as an account of work sponsored by an agency of the United States Government. Neither the United States Government nor any agency thereof, nor Battelle Memorial Institute, nor any of their employees, makes any warranty, express or implied, or assumes any legal liability or responsibility for the accuracy, completeness, or usefulness of any information, apparatus, product, or process disclosed, or represents that its use would not infringe privately owned rights. Reference herein to any specific commercial product, process, or service by trade name, trademark, manufacturer, or otherwise does not necessarily constitute or imply its endorsement, recommendation, or favoring by the United States Government or any agency thereof, or Battelle Memorial Institute. The views and opinions of authors expressed herein do not necessarily state or reflect those of the United States Government or any agency thereof.

\author{
PACIFIC NORTHWEST NATIONAL LABORATORY \\ operated by \\ BATTELLE \\ for the \\ UNITED STATES DEPARTMENT OF ENERGY \\ under Contract DE-AC06-76RL01830
}

This document was printed on recycled paper. 


\title{
Interim Report on Uranium Metal Segregation Testing
}

\author{
A. J. Schmidt \\ M. R. Elmore
}

April 2004

Prepared for

Fluor Hanford and the U.S. Department of Energy under Contract DE-AC06-76RL01830

Pacific Northwest National Laboratory

Richland, Washington 99352 


\section{Contents}

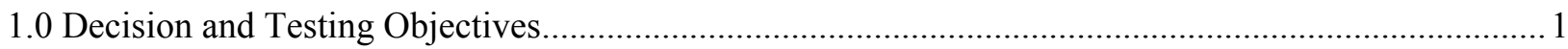

2.0 Summary of Preliminary Results and Conclusions...................................................................

3.0 Technical Uncertainties/Challenges to Implementation .......................................................... 4

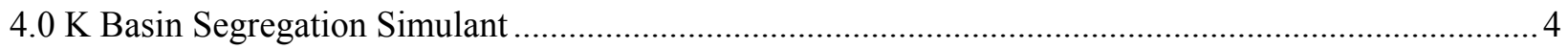

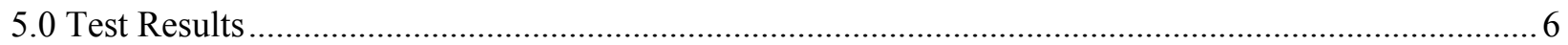

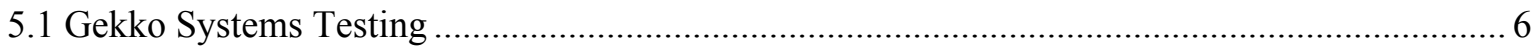

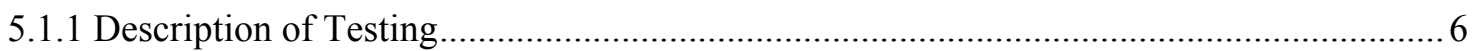

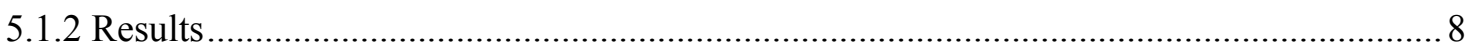

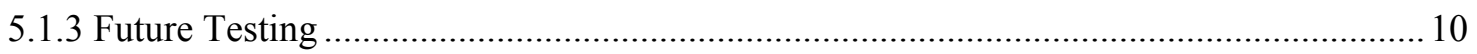

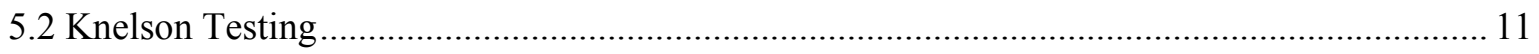

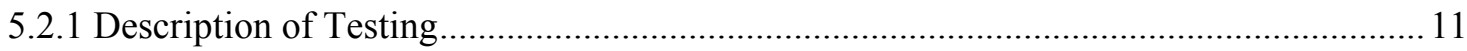

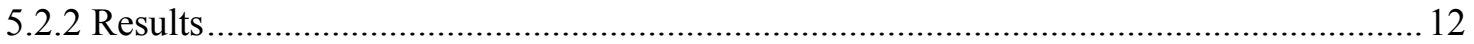

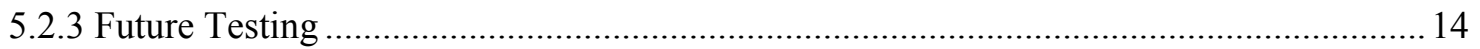

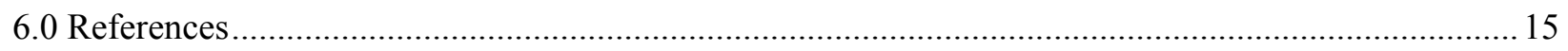

Attachment A - Conceptual K Basin Sludge U-Metal Segregation Process ......................................... A.1

Attachment B - Uranium Metal Segregation Simulant Composition.................................................. 1 


\section{Figures}

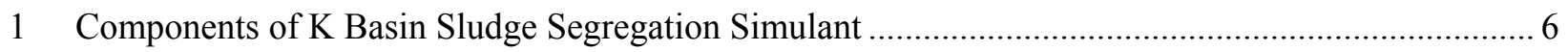

2 Gekko Systems InLine Pressure Jig, Model IPJ600 ................................................................. 7

3 K Basin Segregation Simulant Tabling Recovery-Yield Curve …................................................ 8

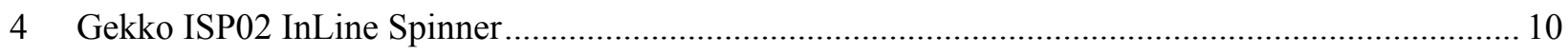

5 Knelson Laboratory-scale Batch Concentrator with a 0-100 lb/hr Feed Capacity .......................... 11

6 Recovery Yield Curve from Lab Concentrator Test with K Basin Segregation Simulant ................. 13

7 Knelson Pilot-Scale Continuous Variable Discharge Concentrator with a 0.6 to 2.2 ton/hr

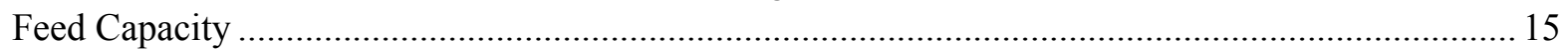

\section{Tables}

1 Methods and Detection Limit for Element Assays ..................................................................... 7

2 Results of Single Pass Tabling Test with K Basin Segregation Simulant ........................................ 9

3 Results from Lab Concentrator Test with K Basin Segregation Simulant ...................................... 12 


\section{Interim Report on Uranium Metal Segregation Testing}

Under contract to Fluor Hanford, the Pacific Northwest National Laboratory directed laboratory and bench-scale vendor testing to evaluate the effectiveness of gravity mineral concentration technology for removing and concentrating uranium metal from Hanford K Basin sludge. The presence of uranium metal fuel particles in the sludge presents a primary challenge to dispositioning it to the Waste Isolation Pilot Plant.

The initial series of vendor testing successfully demonstrated the technical feasibility of using commercial gravity concentration equipment for segregating uranium metal in K Basin sludge. In simple test systems, uranium metal surrogate recoveries of $95 \%$ and greater were achieved. With more prototypical equipment and stream recycle, higher recoveries can likely be achieved. Further testing is underway to examine upgrading of the concentrate stream (i.e., removal of tramp material).

The uranium metal removal requirement for a specific stream depends on a number of factors, including: the uranium metal concentration and particle size distribution (PSD) in the stream, hydrogen gas generation limit for final package, sludge loading in final package, reaction rate mitigation achieved by the solidification matrix, and aging of the package. Ultimately, to assess the effectiveness of gravity concentration equipment, a uranium metal concentration (and PSD) limit in the sludge must be specified.

\subsection{Decision and Testing Objectives}

The current plan for the bulk of the Hanford K East (KE) and K West (KW) Basin sludges [all sludge types except Knock-out Pot (KOP) and North Loadout Pit (NLOP) sludge] is disposition to the Waste Isolation Pilot Plant (WIPP) as remote handled (RH) transuranic (TRU) waste. The primary challenge to dispositioning, however, is the presence of uranium metal fuel particles in the sludge. The metallic uranium within the sludge will corrode, hydrate, and consequently generate heat and hydrogen gas during handling, packaging, shipment, and storage. The hydrogen evolution rate from the sludge, from the reaction of uranium metal and water, likely will drive the number of containers and shipments dispositioned to WIPP. Therefore, to prepare the sludge to meet WIPP waste acceptance criteria (WAC), a uranium metal removal step may be performed. The resulting depleted metal stream would then be solidified in a low-water-content tailored grout.

A technology assessment (Mellinger et al. 2004) concluded that to meet the WIPP hydrogen gas concentration criterion, both a uranium metal removal operation and some reduction of the reaction rate by a solidification matrix will be required. Accordingly, testing is required to establish the technical feasibility of segregation processes and to determine the extent to which the uranium metal can be removed. The segregation process being evaluated is a conventional mineral concentration (gravity) technology. Additional testing is also necessary to understand the effects of a solidification matrix on reducing the uranium metal water reaction (i.e., gas generation testing with uranium metal particles - of known surface area - immobilized in grout, or other suitable solidification matrices).

This report describes the preliminary results of laboratory and bench-scale vendor testing to evaluate the effectiveness of the gravity mineral concentration technology for removing and concentrating uranium metal from sludge. 
The testing to quantify the extent to which the reaction of uranium metal with water is reduced by the solidification matrix will be described in a separate report to be issued in the May-June 2004 timeframe. The results from these two testing activities will need to be considered to assess the overall achievable reduction of the hydrogen gas evolution rate in a final waste package for WIPP and to estimate the waste loading per package.

Background on Conceptual Uranium Metal Segregation Operation: Attachment A describes a conceptual process for K Basin sludge uranium metal segregation. The conceptual K Basin sludge application is very similar to some gold recovery operations. The viability of off-the-shelf mineral concentration technology was initially assessed by contacting a number of mineral concentration equipment vendors and retailers and mineral processing experts. The vendors were provided information on the processing objectives, K Basin sludge physical properties (particle size distribution, particle densities, etc.), and a preconceptual process flow diagram (Figure A.1). Based on discussions with vendor technical staff and mineral processing experts, it was concluded that gravity mineral concentration technology potentially could remove $85 \%$ or more of the uranium metal from the bulk of the K Basin sludge (Mellinger et al. 2004). Removing 90\% of uranium metal from design-basis KE floor sludge would likely satisfy a conservative interpretation ${ }^{(a)}$ of the WIPP hydrogen generation limit.

In the overall process, the uranium metal depleted stream (tails) would be grouted (or solidified in some other matrix) and dispositioned to WIPP as RH-TRU. The uranium metal concentrate stream would be processed (upgraded) to remove tramp material (e.g., uranium oxide/hydrates, aluminum hydroxide nodules, hydrogen/water-bearing constituents). If sufficiently cleaned, the resulting concentrated uranium metal stream could then be dispositioned to multi canister overpacks (MCOs) and dried at the cold vacuum drying (CVD) facility. If the hydrogen/water-bearing content of the final concentrate stream could not be reduced to allow the stream to be dispositioned to the MCOs, another treatment process (e.g., steam/hot water oxidation) may be required to treat this low-volume stream.

During the initial assessment, all of the vendors contacted indicated that bench-scale testing (e.g., shaker table tests, small-scale prototype equipment tests) would be necessary to confirm the technical viability of this application and to provide estimates of the expected uranium metal removal efficiency. The initial results and preliminary conclusions from tests conducted by two vendors are provided here.

\subsection{Summary of Preliminary Results and Conclusions}

For the uranium segregation testing, a K Basin sludge simulant, conservative with respect to uranium metal segregation, was developed. The simulant is further discussed in Section 4.0. Conservative features of the simulant include:

- Use of a cobalt-cemented tungsten carbide (referred to as "W/Co") fragments (250 to $1500 \mu \mathrm{m}$, with average size of $580 \mu \mathrm{m})$ as the surrogate for uranium metal fragments. The slightly lower particle density of the W/Co $\left(14.5 \mathrm{~g} / \mathrm{cm}^{3}\right)$ compared to U metal $\left(19 \mathrm{~g} / \mathrm{cm}^{3}\right)$ increases the recovery challenge.

(a) Based on a maximum hydrogen rate limit (WIPP) of $3.65 \mathrm{E}-08 \mathrm{~mol} / \mathrm{sec}$ at $60^{\circ} \mathrm{C}$ for a 55 -gal drum with grouted waste, and assuming a $40 \mathrm{vol} \%$ waste loading of design-basis KE floor sludge $(71 \mathrm{~L})$. Furthermore, it was assumed that the reaction rate of remaining uranium metal in grout would be one-third of the SNF Databook (Duncan 2001) rate for uranium metal in oxygen-free water. 
- Use of stainless steel spherical powder (minus $120 \mu \mathrm{m}$, average $\sim 60 \mu \mathrm{m}$ ), with a particle density of $\sim 7.8 \mathrm{~g} / \mathrm{cm}^{3}$ as the surrogate for uranium oxy-hydrate species. The average particle density of the non-metallic uranium species in KE floor and canister sludge is estimated to be $7.5 \mathrm{~g} / \mathrm{cm}^{3}$ (Plys and Schmidt 2003). Also, the average particle size of high-uranium-content KE and KW canister sludge after shearing/sonication is less than $60 \mu \mathrm{m}$.

- Use of various grades of Kleen Blast (a sand blasting product, particle density $\sim 2.8 \mathrm{~g} / \mathrm{cm}^{3}$ ) as a surrogate for larger-diameter "inert" sludge particles to create a simulant that contains a higher fraction of plus $500 \mu \mathrm{m}$ particles than KE floor and canister sludge.

- Use of submicron iron oxide monohydrate to increase the viscosity/stickiness of the sludge simulant.

The first series of tests with gravity concentration equipment and $\mathrm{K}$ Basin segregation simulant have been completed. The results are described below.

At Gekko Systems (Australia), $20 \mathrm{~kg}$ (dry basis) of simulant was segregated into a number of fractions using a shaker table. [Gekko uses shaker table results to predict the performance of their In-Line Jig.] Test results show that about $96 \%$ of the W/Co was recovered into about $30 \%$ of the sample mass (using a shaker table). Only about 20 to $25 \%$ of the stainless steel powder was recovered in the concentrate. Based on the $\mathrm{W} /$ Co concentration in the feed material $(3.2 \mathrm{wt} \%)$, the W/Co concentration in the tails stream (i.e., $70 \mathrm{wt} \%$ of the test sample mass) is $0.18 \mathrm{wt} \%$ (by calculation). Based on the promising results, Gekko has been directed to begin the second series of tests, which will involve a segregation step followed by a concentrate upgrading step. The concentrate upgrading step (Gekko's In-Line Spinner) will examine the extent to which the tramp material (non-W/Co components) can be removed. Results from the second series of testing should be available by mid-May.

From the results obtained to date, technical staff at Gekko do not believe a grinding step will be needed to achieve a high uranium metal recovery and clean-up. If required uranium/tramp material removal efficiencies are not achieved in the second series of tests, a third series of testing, which may include a feed grinding stage, may be pursued.

At Knelson Concentrators (Vancouver, B.C.), $4 \mathrm{~kg}$ (dry basis) of simulant was processed (five passes) in a laboratory-scale batch concentrator (centrifugal unit). [Knelson's experience has been that the batch unit typically under-predicts the performance shown in their larger units.] The concentrate collected in the first four passes constituted about $18 \mathrm{wt} \%$ of the test sample mass ( $\sim 13 \mathrm{vol} \%$ of the test sample). This concentrate contained about $96 \%$ of the W/Co originally present in the feed and only about $25 \%$ of the stainless steel powder. Based on the concentration of W/Co in the feed material (3.2 wt\%), the W/Co concentration in the tails stream (i.e., depleted stream that constituted $82 \mathrm{wt} \%(87 \mathrm{vol} \%)$ of the test sample mass) is $0.17 \mathrm{wt} \%$ (by calculation). [Note: the analytical results from the Knelson testing were received on April 22, 2004, and several of the samples will be re-analyzed; therefore, final results may change slightly.] Based on discussions with Knelson technical staff, the test results provide confidence that W/Co can be recovered using Knelson's continuous centrifugal concentrator. Follow-on pilot-scale testing $(200+\mathrm{kg}$ test $)$ is recommended to determine expected removal performance in a full-scale system. The decision to conduct a pilot test will be discussed with Spent Nuclear Fuel/Sludge Project staff. If pursued, the pilot testing (simulant preparation, simulant shipping, testing, sample shipping, and sample analysis) would likely be completed by early June. 
In summary, the initial series of testing (detailed in Section 5.0) demonstrates the technical feasibility of commercial gravity concentration equipment for segregating uranium metal in K Basin sludge. In simple test systems, recoveries of $95 \%$ and greater were achieved. With more prototypical equipment and stream recycle, higher recoveries can likely be achieved. Further testing is underway to examine upgrading of the concentrate stream (i.e., removal of tramp material). Also, to provide higher confidence and better removal efficiency estimates, a pilot-scale test is recommended.

\subsection{Technical Uncertainties/Challenges to Implementation}

While not included in the current scope of testing activities, some technical challenges for deployment of gravity concentration equipment have been identified:

Determination/specification of the uranium metal removal requirement. The removal requirement for a specific stream depends on a number of factors, including: the uranium metal concentration and particle size distribution (PSD) in the stream, hydrogen gas generation limit for final package, sludge loading in final package, reaction rate mitigation achieved by the solidification matrix, and aging of the package.

Ultimately, to assess the effectiveness of gravity concentration equipment, a uranium metal concentration (and PSD) limit in the sludge must be specified.

Measurement of uranium metal concentration in process. To verify the effectiveness of the segregation process, the uranium metal concentration in the concentrate and tails streams may need to be measured. Robust and rapid measurement techniques for the sludge matrix have not been identified. A process test may be necessary to qualify the segregation process, with intermittent verification testing (e.g., gas generation tests) to confirm the process performance.

Handling/storage of uranium metal concentrate stream. Concentrated uranium metal particles will require a vessel designed to address the potential high gas and heat generation rates. Components/features of the concentrate storage/handling system have the potential to be designated as safety significant.

Location/Shielding. The commercial gravity concentration equipment is not typically deployed in radiological or underwater environments. [Note: Gekko has examined at least one underwater deployment.] If located at the K Basins, the equipment will need to be shielded or the designs modified to allow for underwater deployment.

\subsection{K Basin Segregation Simulant}

A sludge simulant was developed specifically to test the viability and performance of vendor equipment for the separation of uranium metal particles from the rest of the $\mathrm{K}$ Basin sludge. The segregation simulant was largely based on a simulant previously characterized and used to evaluate uranium metal distribution during loading of K Basin sludge into containers (Schmidt and Elmore 2002). The vendor mineral concentration equipment employs gravity or density separation methods; therefore, the simulant component selection was focused on characteristics critical to these separation methods (particle size distribution, particle density, and physical behavior). Of particular note is the use of a cobalt-cemented tungsten carbide (referred to as "W/Co") particulate to simulate the uranium metal fragments in the sludge. The W/Co has similar particle size and hardness, and approaches the density of the uranium metal. With the slightly lower density of the W/Co $\left(14.5 \mathrm{~g} / \mathrm{cm}^{3}\right)$ compared to U metal $\left(19 \mathrm{~g} / \mathrm{cm}^{3}\right)$, 
recovery of the $\mathrm{W} / \mathrm{Co}$ from the simulant should be more challenging than recovery of uranium metal from the actual sludge. Stainless steel powder was selected to represent uranium oxides and hydrates. The other simulant components, flyash, silica powder, goethite $\left(\mathrm{Fe}_{2} \mathrm{O}_{3} \cdot \mathrm{H}_{2} \mathrm{O}\right)$, and "Kleen Blast," were chosen to represent the non-uranium remainder of the sludge components (e.g., sand and dust, rust, spalled concrete, aluminum oxide/hydroxide, etc.).

The segregation simulant for vendor testing was prepared by PNNL in accordance with the projectapproved test instruction. ${ }^{\text {(a) }}$ The simulant components, at their respective mass ratios, are shown in Figure 1. Details on the simulant composition and characterization are provided in Attachment B. Attachment B also includes a comparison of the simulant particle size distribution to that of the KE canister and $\mathrm{KE}$ floor sludge.

The metal segregation surrogate composition is summarized below.

- $\mathrm{W} / \mathrm{Co}:=3.2 \mathrm{wt} \%$ (dry simulant basis). KENFCEXP ; $-1500 \mu \mathrm{m}+250 \mu \mathrm{m}$ ), referred to as $\mathrm{W} / \mathrm{Co}$, [having a composition of $6.9 \% \mathrm{Co}, 5.7 \% \mathrm{C}, 0.20 \mathrm{wt} \% \mathrm{Ti}$; balance $(\sim 87 \%)$ is W]. Particle density of W/Co is $\sim 14.5 \mathrm{~g} / \mathrm{cm}^{3}$, bulk dry density, $\sim 10 \mathrm{~g} / \mathrm{cm}^{3}$ ). Particles range from 250 to $1500 \mu \mathrm{m}$, with an average particle size of $\sim 580 \mu \mathrm{m}(50 \%-1500 \mu \mathrm{m},+580 \mu \mathrm{m} ; 50 \%-580 \mu \mathrm{m},+250 \mu \mathrm{m})$.

- $\quad$ SS powder: $=32 \mathrm{wt} \%$ (dry simulant basis). A 434-L stainless steel powder in which all particles are less than $125 \mu \mathrm{m}$, and average particle size (vol) is $\sim 60 \mu \mathrm{m}$.

- Kleen Blast: $=29 \mathrm{wt} \%$ (dry simulant basis). Kleen Blast, a sand blasting product, sold in a range of size distributions, including $-6+8$ mesh, $-8+12$ mesh, and $-16+30$ mesh, will be used to simulate the larger-diameter inert particles. Kleen Blast is roughly composed of $45 \%$ silicon, 23 $\mathrm{wt} \%$ iron oxide, $19 \%$ calcium oxide, and $7 \%$ aluminum; and its particle density is approximately $2.8 \mathrm{~g} / \mathrm{cm}^{3}$. The $29 \mathrm{wt} \%$ will be made up from three grades of Kleen Blast:

$$
\begin{aligned}
-6+8 \text { mesh } & =10 \mathrm{wt} \% \\
-8+12 \text { mesh } & =10 \mathrm{wt} \% \\
-16+30 \text { mesh } & =9 \mathrm{wt} \%
\end{aligned}
$$

- Goethite $=5 \mathrm{wt} \%$. Goethite $(\mathrm{FeOOH})$ (iron III oxide monohydrate). Particle density is $4.0 \mathrm{~g} / \mathrm{cm}^{3}$, and average (vol\%) particle size $0.199 \mu \mathrm{m}$, with $99 \%$ of all particles less than $1 \mu \mathrm{m}$.

- Flyash $=30.8 \times 0.5=15.4 \mathrm{wt} \%$. Class F Flyash, particle density, $\sim 2.2$ to $2.5 \mathrm{~g} / \mathrm{cm}^{3}$. Particles between 0.5 and $180 \mu \mathrm{m}$.

- $\quad$ Min-U-Sil $40=30.8 \times 0.5=15.4 \mathrm{wt} \%$. Ground high purity silica, particle density $=2.65$; mean particle diameter $11 \mu \mathrm{m}$.

(a) Schmidt, A. J. March 9, 2004. "K Basin Sludge Simulant Preparation for Uranium Metal Segregation Testing." Test Instruction 46857-TI05, Pacific Northwest National Laboratory, Richland, WA. 


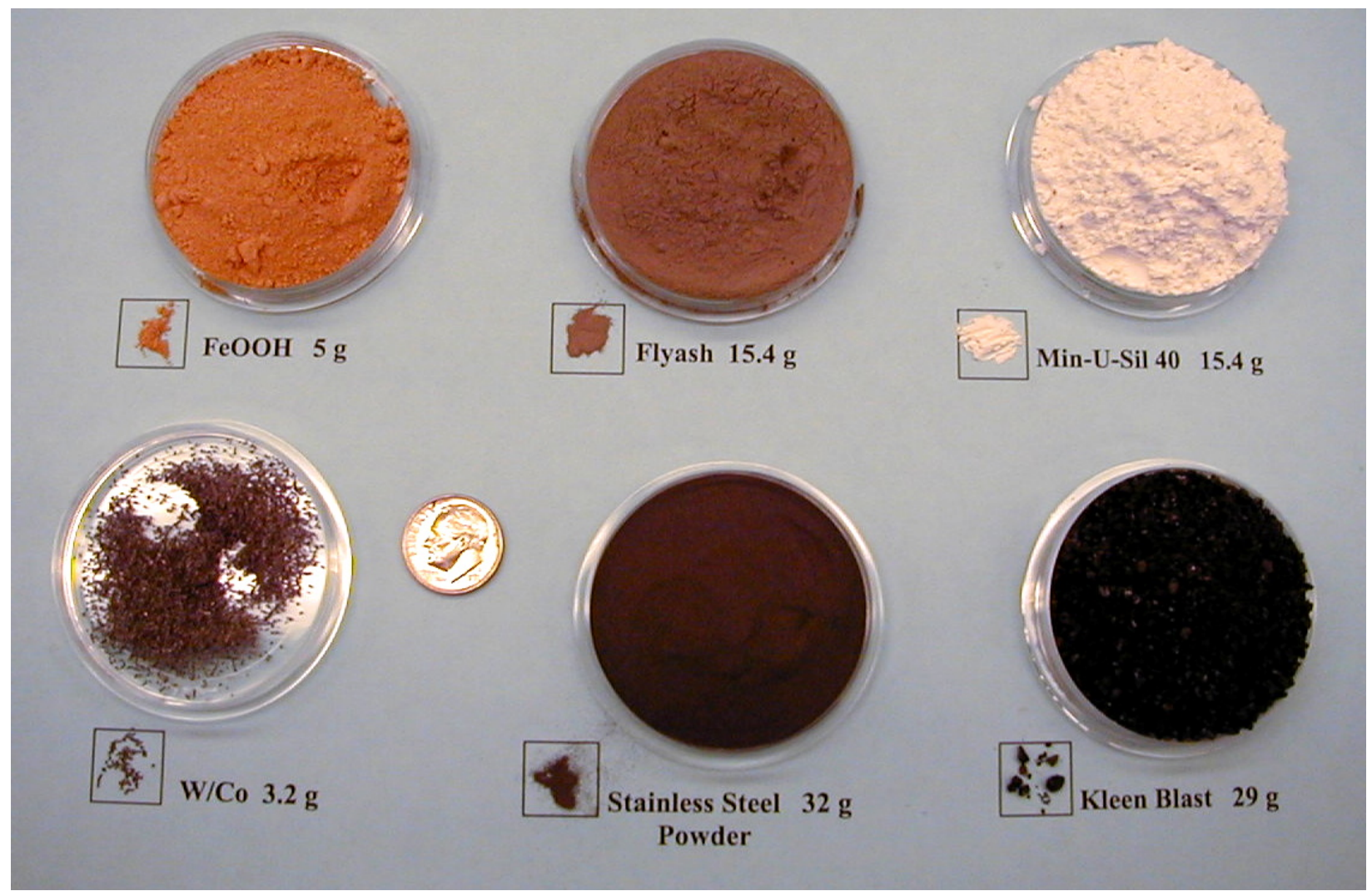

Figure 1. Components of K Basin Sludge Segregation Simulant

\subsection{Test Results}

This section describes the testing conducted at Gekko Systems and Knelson Concentrators, presents the test results, and describes future testing activities.

\subsection{Gekko Systems Testing}

[Additional information on Gekko Systems mineral concentration equipment, installations, and research services can be found at www.gekkos.com.]

\subsubsection{Description of Testing}

To conservatively assess the amenability of uranium metal removal from K Basin sludge by gravity concentration, a bench-scale shaker table test ("tabling") was performed by Gekko Systems using approximately $20 \mathrm{~kg}$ (dry basis) of the $\mathrm{K}$ Basin segregation sludge simulant. In shaker table testing, a slurry is fed to the upper edge of a sloping table (riffled-decked in a horizontal plane). The suspended solids are held up in pools behind the riffles as the material moves across the table. The shaking action of the table results in size classification and specific gravity stratification (Weiss 1985). 
For the first series of testing, simulant provided by PNNL was split (dry), and a representative feed sample was obtained. Next, the sample was mixed with water to form a slurry consisting of about 50 to $60 \mathrm{wt} \%$ solids. The slurry was then processed on a shaker table to determine the potential for single pass gravity uranium (W/Co) recovery. Four concentrate fractions, which together constituted about $31 \mathrm{wt} \%$ (dry basis) of the total feed mass, were collected from the table. The remaining $69 \mathrm{wt} \%$ (dry basis) was collected as a single tails fraction. When the tabling was completed, all fractions were dried and then passed through a 500- $\mu \mathrm{m}$ sieve to produce plus and minus $500-\mu \mathrm{m}$ samples from each fraction.

Representative subsamples were collected from each fraction, and these subsamples were assayed (by laboratories in Australia) for tungsten, cobalt, iron, nickel and chromium to produce a recovery-yield curve for each element. Table 1 summarizes the assay methods and the reported detection limits.

The results of the testing with the sludge simulant correlate to the recoveries achievable in the Gekko InLine Pressure Jig (IPJ) illustrated in Figure 2.

Table 1. Methods and Detection Limit for Element Assays

\begin{tabular}{|c|l|c|}
\hline Analyte & \multicolumn{1}{|c|}{ Technique } & Detection Limit \\
\hline $\mathrm{Ni}, \mathrm{Co}$ & $\begin{array}{l}\text { Mixed acid digest, including hydrofluoric acid, with } \\
\text { atomic absorption spectrometry analysis }\end{array}$ & $2 \mathrm{ppm}, 5 \mathrm{ppm}$ \\
\hline $\mathrm{Cr}, \mathrm{Fe}$ & $\begin{array}{l}\mathrm{Na}_{2} \mathrm{O}_{2} \text { fusion, with inductively coupled plasma (ICP)- } \\
\text { optical emission spectrometry analysis }\end{array}$ & $0.1 \%$ \\
\hline $\mathrm{W}$ & $\mathrm{Na}_{2} \mathrm{O}_{2}$ fusion, with ICP-mass spectrometry analysis & $5 \mathrm{ppm}$ \\
\hline
\end{tabular}

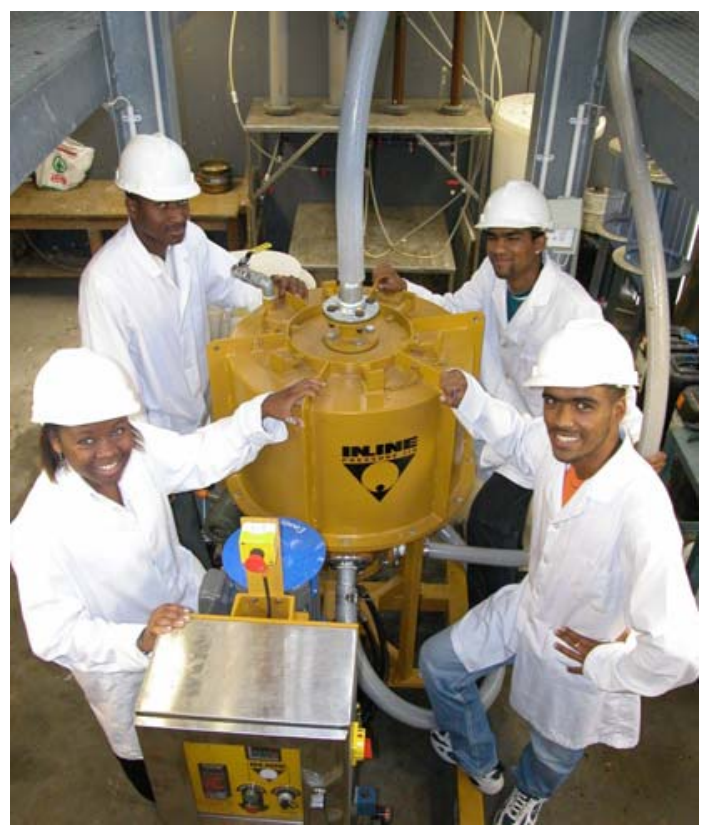

Figure 2. Gekko Systems InLine Pressure Jig, Model IPJ600 [capacity of up to 4 tons per hour (dry solid basis)]. The unit is compact and sealed, and contains only two moving parts. 


\subsubsection{Results}

The results from the first series of tests conducted at Gekko Systems are summarized in Figure 3 and Table 2. Figure 3 shows the recovery of the simulant components as a function of concentrate mass pull (yield). For example, at a mass pull of about $30 \%$, the tungsten recovery is about $95 \%$. As expected, the cobalt recovery tracks with the tungsten recovery. [The W/Co fragments used as a surrogate for uranium metal are about $87 \mathrm{wt} \% \mathrm{~W}, 6.9 \mathrm{wt} \% \mathrm{Co}$, and $5.7 \mathrm{wt} \% \mathrm{C}$.] Based on the $\mathrm{W} /$ Co concentration in the feed material (3.2 $\mathrm{wt} \%)$, the $\mathrm{W} /$ Co concentration in the tails stream (i.e., $70 \mathrm{wt} \%$ of the test sample mass) is $0.18 \mathrm{wt} \%$, by calculation. By assay, the tails stream was found to contain $0.10 \mathrm{wt} \% \mathrm{~W} / \mathrm{Co}$.

The iron, nickel, and chromium (mostly present as stainless steel powder), exhibited similar behavior, with recoveries ranging from 20 to $25 \%$ at a mass pull of $30 \%$. The behavior of iron, nickel, and chromium is a good indication that uranium oxides/hydrates can be effectively segregated from uranium metal.

As shown in Table 2, recoveries were determined in both $+500 \mu \mathrm{m}$ and $-500 \mu \mathrm{m}$ fractions for each sample. Recovery results were similar, however, at a $30.6 \mathrm{wt} \%$ mass pull; $98 \%$ of the $+500 \mu \mathrm{m} \mathrm{W} / \mathrm{Co}$ was recovered in the concentrate, while $91 \%$ of the $-500 \mu \mathrm{m}$ W/Co was recovered.

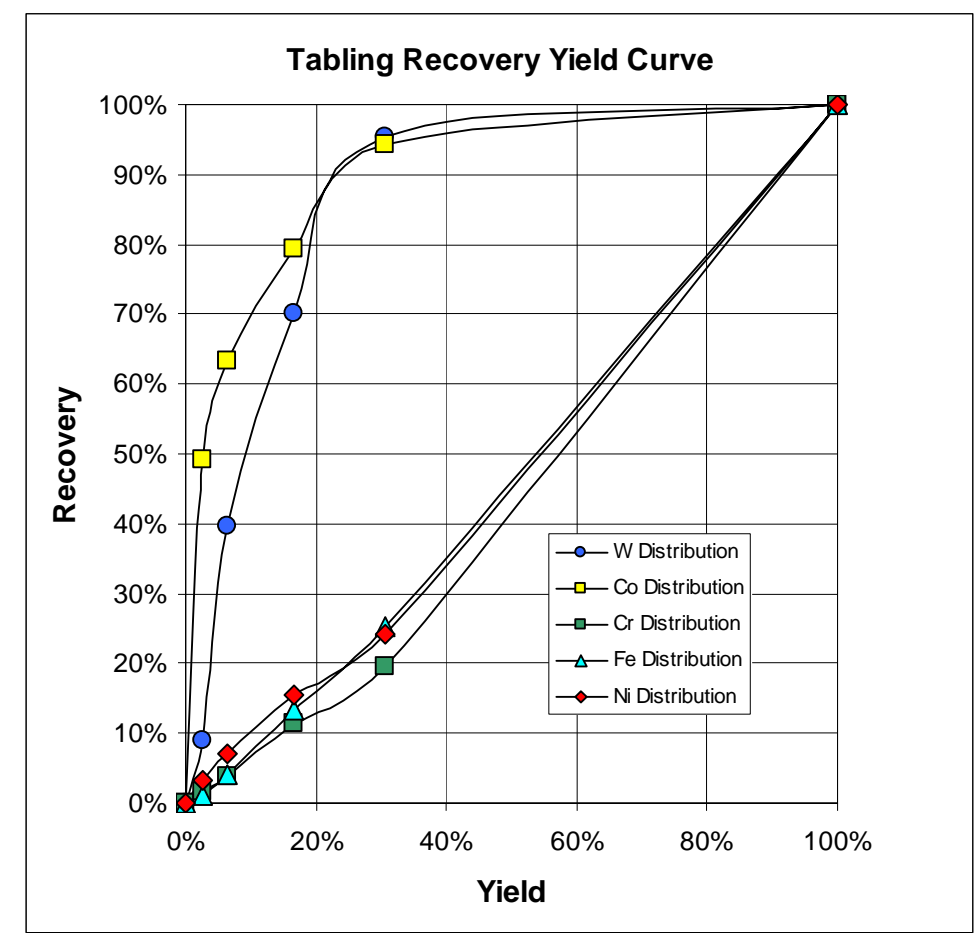

Figure 3. K Basin Segregation Simulant Tabling Recovery-Yield Curve. [Recoveries of tungsten (W), cobalt $(\mathrm{Co})$, chromium $(\mathrm{Cr})$, iron $(\mathrm{Fe})$, and nickel $(\mathrm{Ni})$ as a function of percent mass recovered to concentrate stream (yield).] 
Table 2. Results of Single Pass Tabling Test with K Basin Segregation Simulant

\begin{tabular}{|c|c|c|c|c|c|c|c|c|c|c|c|}
\hline \multirow[t]{2}{*}{ Sample } & \multicolumn{3}{|c|}{ Mass Yield on Table } & \multicolumn{4}{|c|}{ Tungsten Distribution on Table } & \multicolumn{4}{|c|}{ Cobalt Distribution on Table } \\
\hline & $\mathbf{g}$ & $\%$ & $\begin{array}{c}\text { cumulative } \\
\%\end{array}$ & $\begin{array}{c}\text { Assay } \\
\%\end{array}$ & $\begin{array}{c}\text { Distribution } \\
\%\end{array}$ & \begin{tabular}{c|} 
Cumulative \\
Distribution
\end{tabular} & $\begin{array}{c}\text { Cumulative } \\
\text { grade } \%\end{array}$ & $\begin{array}{l}\text { Assay } \\
\text { ppm }\end{array}$ & $\begin{array}{c}\text { Distribution } \\
\% \\
\end{array}$ & $\begin{array}{l}\text { Cumulative } \\
\text { Distribution } \\
\end{array}$ & $\begin{array}{l}\text { Cumulative } \\
\text { grade ppm }\end{array}$ \\
\hline Concentrate 1 (+500um) & 275.07 & $1.4 \%$ & $1.4 \%$ & 4.04 & $4.1 \%$ & $4 \%$ & 4.0 & 50800 & $30.6 \%$ & $31 \%$ & 50800.0 \\
\hline Concentrate 1 (-500um) & 219.70 & $1.1 \%$ & $2.5 \%$ & 5.93 & $4.8 \%$ & $9 \%$ & 4.9 & 38600 & $18.6 \%$ & $49 \%$ & 45382.7 \\
\hline Concentrate 2 (+500um) & 554.50 & $2.8 \%$ & $5.3 \%$ & 11.50 & $23.5 \%$ & $32 \%$ & 8.4 & 8000 & $9.7 \%$ & $59 \%$ & 25627.3 \\
\hline Concentrate 2 (-500um) & 248.94 & $1.3 \%$ & $6.5 \%$ & 7.86 & $7.2 \%$ & $40 \%$ & 8.3 & 8400 & $4.6 \%$ & $63 \%$ & 22323.9 \\
\hline Concentrate 3 (+500um) & 1387.00 & $7.0 \%$ & $13.5 \%$ & 4.18 & $21.4 \%$ & $61 \%$ & 6.2 & 3300 & $10.0 \%$ & $73 \%$ & 12497.4 \\
\hline Concentrate 3 (-500um) & 625.10 & $3.1 \%$ & $16.6 \%$ & 4.01 & $9.3 \%$ & $70 \%$ & 5.8 & 4300 & $5.9 \%$ & $79 \%$ & 10949.5 \\
\hline Concentrate 4 (+500um) & 2139.60 & $10.8 \%$ & $27.4 \%$ & 2.15 & $17.0 \%$ & $87 \%$ & 4.3 & 2080 & $9.7 \%$ & $89 \%$ & 7467.4 \\
\hline Concentrate 4 (-500um) & 646.10 & $3.2 \%$ & $30.6 \%$ & 3.49 & $8.3 \%$ & $96 \%$ & 4.2 & 3760 & $5.3 \%$ & $94 \%$ & 7074.4 \\
\hline Table Tails(+500um) & 2070 & $10.4 \%$ & $41.0 \%$ & 0.20 & $1.5 \%$ & $97 \%$ & 3.2 & 220 & $1.0 \%$ & $95 \%$ & 5336.9 \\
\hline Table Tails(-500um) & 11730 & $59.0 \%$ & $100.0 \%$ & 0.07 & $2.8 \%$ & $100 \%$ & 1.4 & 180 & $4.6 \%$ & $100 \%$ & 2296.6 \\
\hline Calc'd Feed & 19896 & $100.0 \%$ & & 1.36 & $100.0 \%$ & & 1.4 & 2296.6 & $100.0 \%$ & & 2296.6 \\
\hline Assay Feed & 19720 & $100.0 \%$ & & 2.58 & 100.00 & 100.00 & & 2480 & 100.00 & 100.00 & \\
\hline \multicolumn{4}{|c|}{ Chromium Distribution on Table } & \multicolumn{4}{|c|}{ Iron Distribution on Table } & \multicolumn{4}{|c|}{ Nickel Distribution on Table } \\
\hline $\begin{array}{l}\text { Assay } \\
\text { ppm }\end{array}$ & $\begin{array}{c}\text { Distribution } \\
\% \\
\end{array}$ & $\begin{array}{l}\text { Cumulative } \\
\text { Distribution } \\
\end{array}$ & $\begin{array}{l}\text { Cumulative } \\
\text { grade ppm }\end{array}$ & $\begin{array}{c}\text { Assay } \\
\%\end{array}$ & $\begin{array}{c}\text { Distribution } \\
\% \\
\end{array}$ & \begin{tabular}{c|} 
Cumulative \\
Distribution \\
\end{tabular} & $\begin{array}{c}\text { Cumulative } \\
\text { grade } \%\end{array}$ & $\begin{array}{l}\text { Assay } \\
\text { ppm }\end{array}$ & $\begin{array}{c}\text { Distribution } \\
\% \\
\end{array}$ & $\begin{array}{l}\text { Cumulative } \\
\text { Distribution }\end{array}$ & $\begin{array}{l}\text { Cumulative } \\
\text { grade ppm }\end{array}$ \\
\hline 2159 & $0.1 \%$ & $0 \%$ & 2159.0 & 4.1 & $0.2 \%$ & $0 \%$ & 4.1 & 950.0 & $1.0 \%$ & $1 \%$ & 950.0 \\
\hline 65500 & $1.4 \%$ & $1 \%$ & 30285.2 & 32.9 & $1.1 \%$ & $1 \%$ & 16.9 & 2790.0 & $2.3 \%$ & $3 \%$ & 1767.0 \\
\hline 622 & $0.0 \%$ & $2 \%$ & 14609.3 & 17.5 & $1.4 \%$ & $3 \%$ & 17.2 & 200.0 & $0.4 \%$ & $4 \%$ & 938.9 \\
\hline 87100 & $2.2 \%$ & $4 \%$ & 28509.9 & 42.4 & $1.5 \%$ & $4 \%$ & 22.0 & 3440.0 & $3.3 \%$ & $7 \%$ & 1418.5 \\
\hline 602 & $0.1 \%$ & $4 \%$ & 14094.5 & 17.6 & $3.6 \%$ & $8 \%$ & 19.7 & 90.0 & $0.5 \%$ & $7 \%$ & 732.3 \\
\hline 123000 & $7.7 \%$ & $11 \%$ & 34659.6 & 61.7 & $5.6 \%$ & $13 \%$ & 27.7 & 3360.0 & $8.0 \%$ & $15 \%$ & 1228.5 \\
\hline 540 & $0.1 \%$ & $12 \%$ & 21264.5 & 18.0 & $5.6 \%$ & $19 \%$ & 23.9 & 70.0 & $0.6 \%$ & $16 \%$ & 773.7 \\
\hline 125000 & $8.1 \%$ & $20 \%$ & 32259.1 & 64.7 & $6.1 \%$ & $25 \%$ & 28.2 & 3370.0 & $8.3 \%$ & $24 \%$ & 1048.9 \\
\hline 566 & $0.1 \%$ & $20 \%$ & 24225.2 & 17.6 & $5.3 \%$ & $30 \%$ & 25.5 & 50.0 & $0.4 \%$ & $25 \%$ & 795.7 \\
\hline 68600 & $80.3 \%$ & $100 \%$ & 50387.1 & 40.5 & $69.5 \%$ & $100 \%$ & 34.3 & 1690.0 & $75.3 \%$ & $100 \%$ & 1322.9 \\
\hline 50387.1 & $100.0 \%$ & & 50387.1 & 34.3 & $100.0 \%$ & & 34.3 & 1322.9 & $100.0 \%$ & & 1322.9 \\
\hline 48800 & 100.00 & 100.00 & & 36.70 & 100.00 & 100.00 & & 1150.00 & 100.00 & 100.00 & \\
\hline
\end{tabular}




\subsubsection{Future Testing}

Based on the recoveries achieved in the first series of testing, a single pass tabling, with $20 \mathrm{~kg}$ simulant, will be performed to pull approximately $30 \%$ (dry mass basis) to the concentrate stream. The table fractions (concentrate and tails) will be sampled and assayed. Next, a cleaning test will be performed on the concentrate sample using a bench-scale InLine Spinner (ISP) to upgrade the concentrate from the tabling. The fraction from the ISP will be sampled and assayed for tungsten, cobalt, iron, nickel, and chromium to produce a recovery-yield curve for each element. From this testing, an estimate of efficiency of the tramp material removal from the concentrate stream will be provided. Additionally, the results will be used to confirm the results obtained from the first series of tabling tests. Figure 4 shows a process-scale InLine Spinner.

If the Spent Nuclear Fuel/Sludge Project determines that higher levels of uranium metal removal are required, or higher levels of tramp removal are needed, a third series of testing may be conducted by Gekko Systems. The third test may examine the potential benefits of adding a grinding step to the process to reduce the particle size of the larger non-uranium particles in the simulant. The future testing could also examine the benefits of recycling the tails through the concentrator (shaker table) in an effort to increase the uranium metal removal efficiency.

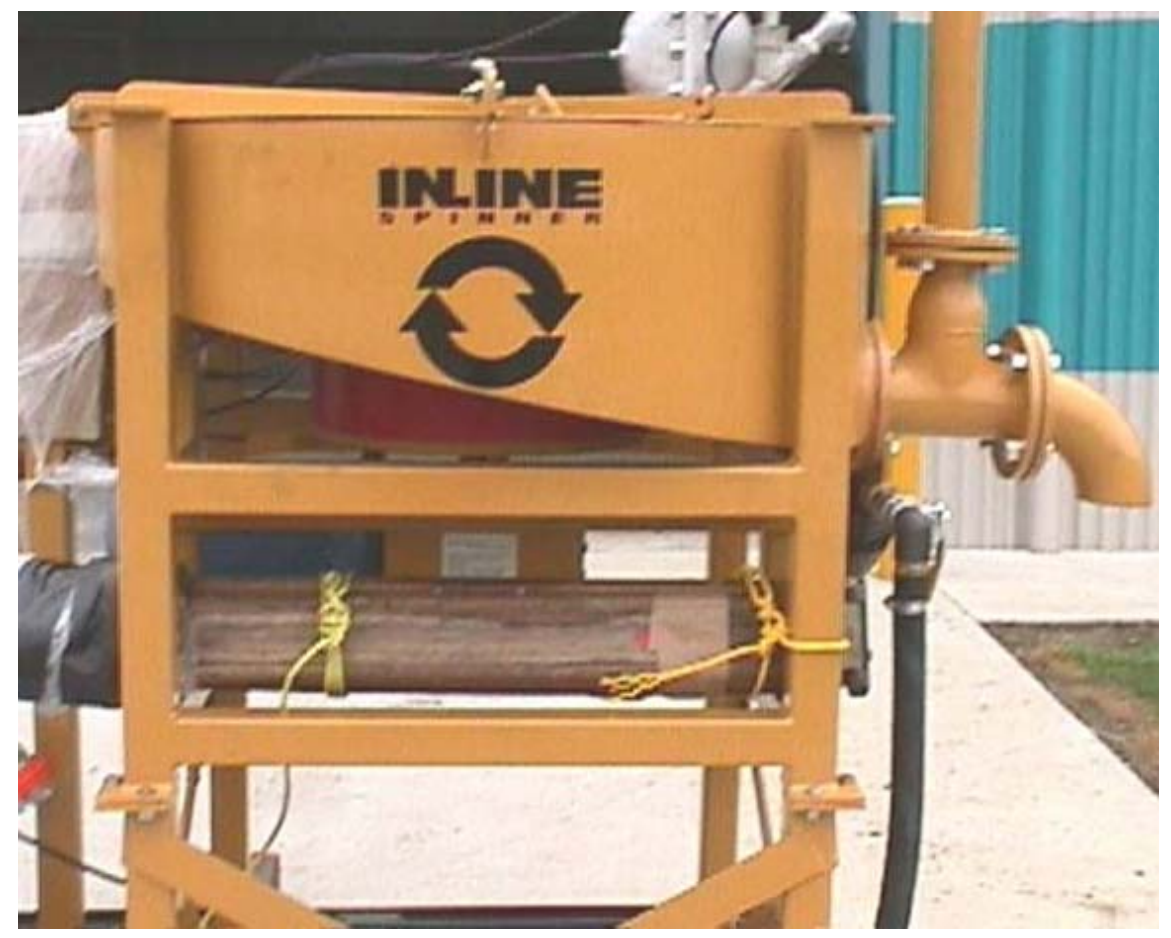

Figure 4. Gekko ISP02 InLine Spinner [can process up to 3 tons per hour (dry solid basis)] 


\subsection{Knelson Testing}

[Additional information on Knelson Concentrators mineral concentration equipment, installations, and research services can be found at www.knelson.com.]

\subsubsection{Description of Testing}

Testing was conducted at Knelson to evaluate the performance of their laboratory-scale batch centrifugal concentrator (KC-MD3 - Figure 5) with the K Basin segregation simulant. Four kilograms of simulant (dry basis) was shipped to Knelson and was processed in five passes through the laboratory concentrator. Operating in a batch mode, the full mass of simulant was fed to the concentrator, followed by fluidization and segregation. For each pass, a small mass pull, representing about 3 to $5 \mathrm{wt} \%$ of the simulant was removed as the concentrated stream of higher-density components of the simulant. The concentrate and remainder (tails) were then dried and weighed. A small $(\sim 100 \mathrm{~g})$ sample of the tails was split from the total for later analysis, along with the concentrate. The remainder of the tails was then slurried with water and fed back to the concentrator for the next cycle. Knelson reported a typical, well-behaved separation with the concentrator.

All samples were sent to PNNL for analysis. At PNNL, the samples were split with a riffle-splitter to provide $\sim 10$-g subsamples to EMSL Laboratory 1421/1422. In the laboratory, a minimum of 0.2 to a maximum of $0.4 \mathrm{~g}$ was digested in trace metal grade acid $(10 \mathrm{ml}$ conc. nitric and $5 \mathrm{ml}$ conc. hydrofluoric), twice for $30 \mathrm{~min}$ at $200^{\circ} \mathrm{C}$. Next, $35 \mathrm{ml}$ of $4 \%$ boric acid was added, and the solution was digested for an additional $30 \mathrm{~min}$ at $165^{\circ} \mathrm{C}$. The digestions were performed in a CEM MES microwave using temperature and pressure control. The solution was then diluted to mark in a 100-ml volumetric flask. The solutions were analyzed in a Perkin Elmer 3000DV ICP-OES. Calibration was made using NISTcertified standards. A second set of NIST-certified standards from a different vendor were used to verify the calibration to $\pm 10 \%$.

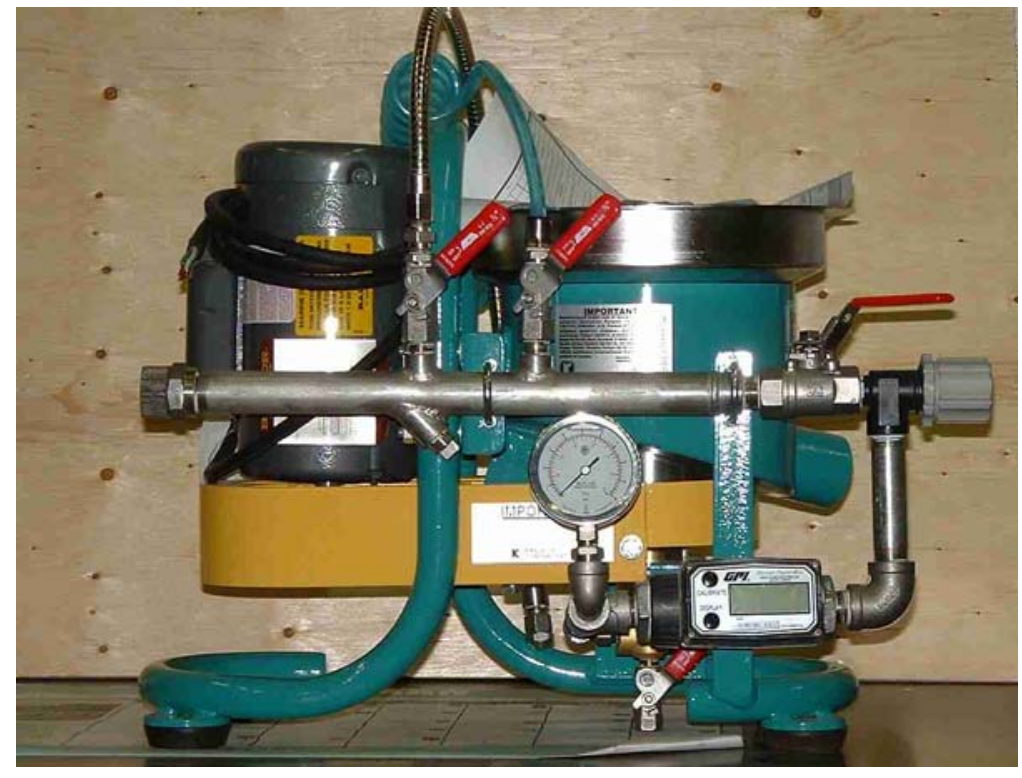

Figure 5. Knelson Laboratory-scale Batch Concentrator (KC-MD3) with a 0-100 lb/hr Feed Capacity 


\subsubsection{Results}

The results from the first series of tests conducted at Knelson are summarized in Table 3. Table 3 includes results from concentrates and tails from each pass through the concentrator. Typically, a tails

Table 3. Results from Lab Concentrator Test (5 Passes) with K Basin Segregation Simulant

\begin{tabular}{|c|c|c|c|c|c|c|c|c|c|c|}
\hline \multirow[b]{2}{*}{ Sample \# } & \multirow[b]{2}{*}{ Name } & \multirow[b]{2}{*}{ Description } & \multicolumn{2}{|c|}{ Sample Fractions } & \multicolumn{3}{|c|}{ Tungsten } & \multicolumn{3}{|c|}{ Cobalt } \\
\hline & & & $\begin{array}{c}\text { Reported } \\
\text { Mass, } g\end{array}$ & $\begin{array}{l}\text { Wt \% of } \\
\text { Sample }\end{array}$ & $\begin{array}{l}\text { Wto in } \\
\text { Sample }\end{array}$ & $\begin{array}{c}\text { Mass in } \\
\text { Fraction, } \mathrm{g}\end{array}$ & $\begin{array}{l}\text { Wt } \% \text { of } \\
\text { Total }\end{array}$ & $\begin{array}{l}\text { Wt } \% \text { in } \\
\text { Sample }\end{array}$ & $\begin{array}{c}\text { Mass in } \\
\text { Fraction, } \mathrm{g}\end{array}$ & $\begin{array}{l}\mathrm{Wt} \% \text { of } \\
\text { Total }\end{array}$ \\
\hline 9406 & Ai Concentrate & \begin{tabular}{|l|} 
First Pass \\
Concentrate \\
\end{tabular} & 220.0 & 5.60 & 36.46 & 80.22 & 59.33 & 2.000 & 4.399 & 56.06 \\
\hline 9407 & Ai MD3 Tails & \begin{tabular}{|l|}
$\begin{array}{l}\text { First Pass Tails } \\
\text { subsample }\end{array}$ \\
\end{tabular} & 98.1 & 2.50 & 7.08 & 6.95 & 5.14 & 0.366 & 0.360 & 4.58 \\
\hline 9408 & Aii Concentrate & \begin{tabular}{|l|} 
Second Pass \\
Concentrate \\
\end{tabular} & 182.0 & 4.63 & 13.14 & 23.92 & 17.69 & 0.964 & 1.755 & 22.36 \\
\hline 9409 & Aii MD3 Tails & $\begin{array}{l}\text { Second Pass Tails } \\
\text { subsample }\end{array}$ & 109.7 & 2.79 & 0.88 & 0.97 & 0.71 & 0.061 & 0.067 & 0.86 \\
\hline 9410 & Aiii Concentrate & \begin{tabular}{|l|} 
Third Pass \\
Concentrate
\end{tabular} & 150.2 & 3.83 & 8.97 & 13.48 & 9.97 & 0.560 & 0.841 & 10.71 \\
\hline 9411 & Aiii MD3 Tails & \begin{tabular}{|l|} 
Third Pass Tails \\
subsample
\end{tabular} & 100.5 & 2.56 & 0.84 & 0.84 & 0.62 & 0.061 & 0.061 & 0.78 \\
\hline 9412 & Aiv Concentrate & \begin{tabular}{|l|} 
Fourth Pass \\
Concentrate
\end{tabular} & 156.0 & 3.97 & 2.64 & 4.13 & 3.05 & 0.142 & 0.221 & 2.81 \\
\hline 9413 & Aiv MD3 Tails & \begin{tabular}{|l|}
$\begin{array}{l}\text { Fourth Pass Tails } \\
\text { subsample }\end{array}$ \\
\end{tabular} & 112.1 & 2.85 & 0.24 & 0.27 & 0.20 & 0.009 & 0.010 & 0.12 \\
\hline 9414 & Av Concentrate & \begin{tabular}{|l|} 
Fitth Pass \\
Concentrate \\
\end{tabular} & 150.9 & 3.84 & 0.11 & 0.17 & 0.13 & 0.018 & 0.027 & 0.35 \\
\hline 9415 & Av MD3 Tails & $\begin{array}{l}\text { Fifth Pass Tails } \\
\text { subsample }\end{array}$ & 117.2 & 2.98 & 0.16 & 0.19 & 0.14 & 0.004 & 0.005 & 0.06 \\
\hline 9416 & Av MD3 Tails Bulk & \begin{tabular}{|l|} 
Fifth Pass Tails \\
bulk final tails
\end{tabular} & 2530.0 & 64.43 & 0.16 & 4.09 & 3.02 & 0.004 & 0.102 & 1.30 \\
\hline & & Total & 3926.70 & 100.00 & & 135.21 & 100.00 & & 7.85 & 100.00 \\
\hline & & $\mathrm{Wt} \%$ in all fractic & & & 3.44 & & & 0.20 & & \\
\hline
\end{tabular}

\begin{tabular}{|c|c|c|c|c|c|c|c|c|c|c|}
\hline \multirow[b]{2}{*}{ Sample \# } & \multirow[b]{2}{*}{ Description } & \multicolumn{3}{|c|}{ Iron } & \multicolumn{3}{|c|}{ Chromium } & \multicolumn{3}{|c|}{ Nickel } \\
\hline & & Wt\% in Sample & $\begin{array}{c}\text { Mass in } \\
\text { Fraction, } \mathrm{g}\end{array}$ & $\begin{array}{c}\text { Wt } \% \text { of } \\
\text { Total }\end{array}$ & $\begin{array}{l}\text { Wt\% in } \\
\text { Sample }\end{array}$ & $\begin{array}{c}\text { Mass in } \\
\text { Fraction, } \mathrm{g}\end{array}$ & $\begin{array}{c}\mathrm{Wt} \% \text { of } \\
\text { Total }\end{array}$ & $\begin{array}{l}\mathrm{Wt} \% \text { in } \\
\text { Sample }\end{array}$ & $\begin{array}{c}\text { Mass in } \\
\text { Fraction, } \mathrm{g}\end{array}$ & $\begin{array}{c}\text { Wt } \% \text { of } \\
\text { Total }\end{array}$ \\
\hline 9406 & \begin{tabular}{|l|} 
First Pass \\
Concentrate
\end{tabular} & 28.28 & 62.22 & 6.25 & 3.17 & 6.97 & 8.32 & 0.18 & 0.39 & 7.92 \\
\hline 9407 & \begin{tabular}{|l|}
$\begin{array}{l}\text { First Pass Tails } \\
\text { subsample }\end{array}$ \\
\end{tabular} & 21.61 & 21.20 & 2.13 & 1.57 & 1.54 & 1.83 & 0.09 & 0.09 & 1.86 \\
\hline 9408 & $\begin{array}{l}\text { Second Pass } \\
\text { Concentrate }\end{array}$ & 31.56 & 57.44 & 5.77 & 3.47 & 6.31 & 7.53 & 0.18 & 0.34 & 6.81 \\
\hline 9409 & $\begin{array}{l}\text { Second Pass Tails } \\
\text { subsample }\end{array}$ & 23.09 & 25.33 & 2.54 & 1.83 & 2.00 & 2.39 & 0.10 & 0.11 & 2.22 \\
\hline 9410 & $\begin{array}{l}\text { Third Pass } \\
\text { Concentrate }\end{array}$ & 31.99 & 48.05 & 4.83 & 3.43 & 5.15 & 6.14 & 0.18 & 0.27 & 5.57 \\
\hline 9411 & $\begin{array}{l}\text { Third Pass Tails } \\
\text { subsample }\end{array}$ & 26.22 & 26.35 & 2.65 & 2.23 & 2.24 & 2.67 & 0.12 & 0.12 & 2.44 \\
\hline 9412 & \begin{tabular}{|l|} 
Fourth Pass \\
Concentrate
\end{tabular} & 26.21 & 40.89 & 4.11 & 2.54 & 3.96 & 4.72 & 0.12 & 0.18 & 3.67 \\
\hline 9413 & $\begin{array}{l}\text { Fourth Pass Tails } \\
\text { subsample }\end{array}$ & 24.04 & 26.95 & 2.71 & 1.91 & 2.14 & 2.55 & 0.11 & 0.12 & 2.43 \\
\hline 9414 & \begin{tabular}{|l|} 
Fitth Pass \\
Concentrate
\end{tabular} & 38.09 & 57.48 & 5.77 & 4.00 & 6.04 & 7.20 & 0.18 & 0.27 & 5.48 \\
\hline 9415 & $\begin{array}{l}\text { Fifth Pass Tails } \\
\text { subsample }\end{array}$ & 23.79 & 27.88 & 2.80 & 1.80 & 2.10 & 2.51 & 0.11 & 0.13 & 2.73 \\
\hline 9416 & $\begin{array}{l}\text { Fifth Pass Tails bulk } \\
\text { final tails } \\
\end{array}$ & 23.79 & 601.90 & 60.45 & 1.80 & 45.41 & 54.15 & 0.11 & 2.90 & 58.87 \\
\hline & Total & & 995.69 & 10000 & & 8387 & 100.00 & & 4.92 & 100.00 \\
\hline $\mathrm{Wt} \%$ in all & fractions & 25.36 & & & 2.14 & & & 0.13 & & \\
\hline
\end{tabular}


sample is not collected until the last pass, as the intermediate tails samples contain some of the component of interest $(\mathrm{W} / \mathrm{Co})$ that would otherwise be recovered in the concentrate in subsequent passes. However, in this test series, intermediate tails samples were collected to provide additional data to better understand the concentrator performance. Almost $60 \%$ of the $\mathrm{W} / \mathrm{Co}$ was collected in the first pass, which constituted about $5.6 \mathrm{wt} \%$ of the total test sample mass. About $28 \%$ of the W/Co was recovered in the second and third pass concentrates. In the fourth pass, only about $4 \%$ of the $\mathrm{W} / \mathrm{Co}$ was recovered. Table 3 shows that very little additional $\mathrm{W} / \mathrm{Co}$ was collected in the concentrate in the fifth pass.

Figure 6 shows the recovery of the simulant components as a function of concentrate mass (yield). To construct Figure 6, the concentrations of analytes in all intermediate tails samples (samples 9407, 9409, 9411, and 9413) were assumed to be at the concentrations of the final tails sample (9415). The concentrate collected in the first four passes constituted about $18 \mathrm{wt} \%$ of the test sample mass. This concentrate contained about $96 \%$ of the W/Co originally present in the feed and only about $25 \%$ of the stainless steel powder. Based on the concentration of W/Co in the feed material $(3.2 \mathrm{wt} \%)$, the W/Co

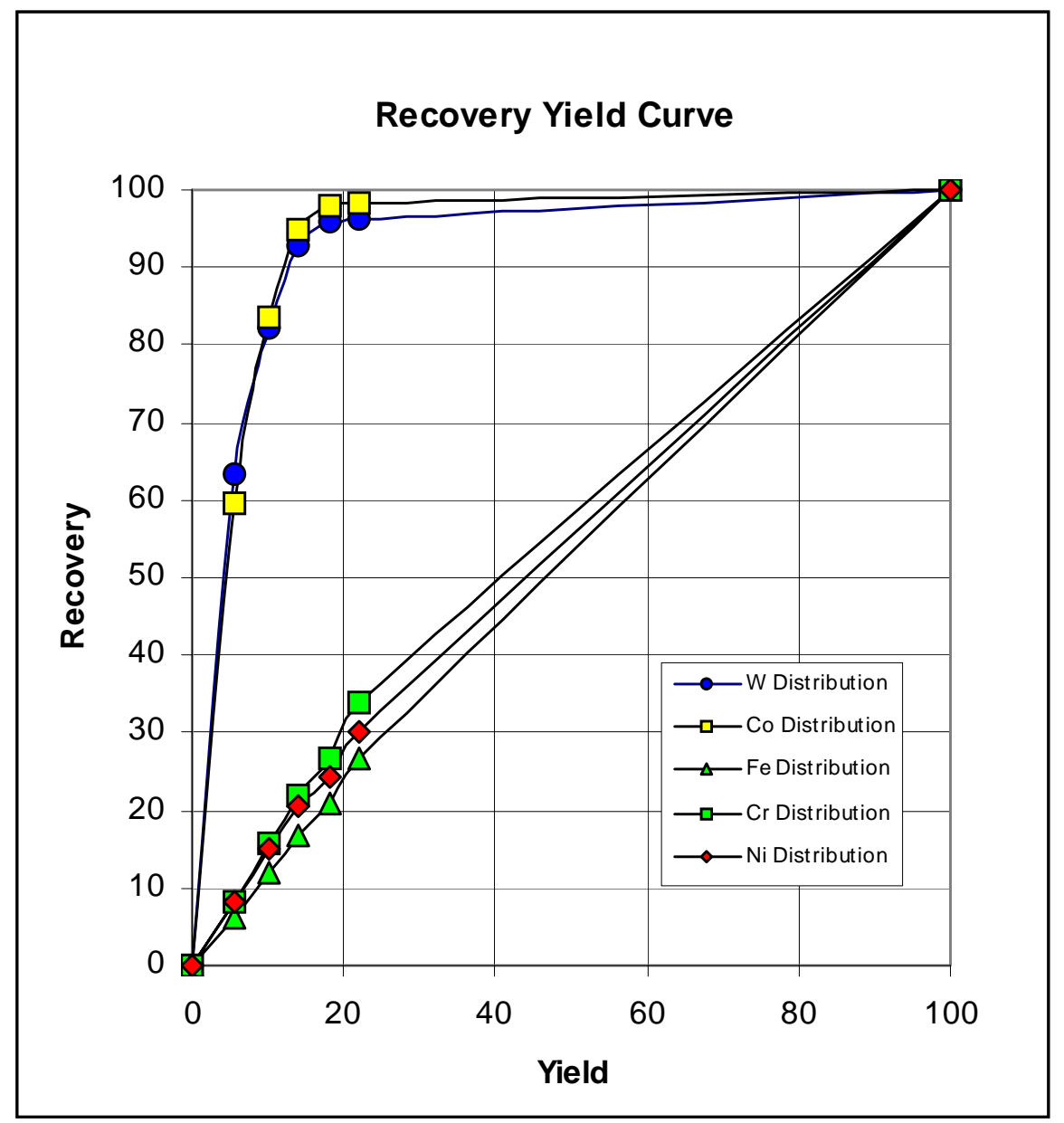

Figure 6. Recovery Yield Curve from Lab Concentrator Test (5 Passes) with K Basin Segregation Simulant. [Recoveries of tungsten (W), cobalt (Co), chromium $(\mathrm{Cr})$, iron (Fe), and nickel (Ni) as a function of percent mass recovered to concentrate stream (yield).] 
concentration in the tails stream (i.e., depleted stream that constituted $82 \mathrm{wt} \%$ of the test sample mass) is $0.17 \mathrm{wt} \%$ (by calculation). By assay, the tails stream from the fifth pass was found to contain $\sim 0.18 \mathrm{wt} \%$ W/Co.

From Figure 6 , about $93 \%$ of the tungsten (and 95\% of the cobalt) was recovered in the concentrate from the first three passes (which make up $14 \mathrm{wt} \%$ of the sample mass).

To estimate the volume of the concentrates and final tails, the bulk dry densities of selected samples were measured. The bulk densities of the concentrates from the first four passes (samples 9406, 9408, 9410

and 9412 ) are $3.5,3.0,2.6$, and $2.2 \mathrm{~g} / \mathrm{cm}^{3}$, respectively. The bulk density of the final tails sample (9415) was $1.9 \mathrm{~g} / \mathrm{cm}^{3}$. Based on these bulk densities, the first three concentrates constitute $9.3 \mathrm{vol} \%$ of the total sample volume, and the first four concentrates constitute $13 \mathrm{vol} \%$ of the total sample volume. Likewise, the W/Co depleted stream (tails) from this testing constitutes 87 to 91 vol\% of the total sample.

\subsubsection{Future Testing}

Based on the results of the first series of testing, Knelson staff are confident they can recover the W/Co using their gravity separation equipment and believe subsequent pilot-scale testing is warranted. Results from a larger, pilot-scale continuous centrifugal variable discharge concentrator (also known as the CVD) can be used to estimate the performance expected from full-scale operations.

The objective for the pilot work will be to test and confirm that the Knelson CVD (Figure 7) will indeed achieve a high W/Co removal efficiency and produce a concentrate stream with a high W/Co content.

The pilot-scale testing will include the following activities:

1. PNNL will prepare and ship $\sim 240 \mathrm{~kg}$ of simulant.

2. Knelson will test the larger sample of simulant in their pilot-scale concentrator processing equipment.

3. Knelson will perform an initial scoping test to obtain the proper valve timings. No samples will be collected from this test, as it is more of a mechanical response test.

4. Once the machine's operational parameters are determined at the desired set points, Knelson will run a test (pilot-scale test 1) to remove the W/Co. Samples will be collected for analysis.

5. The tails from test 1 will be run again (pilot-scale test 2) to scavenge the simulant material for more W/Co.

6. The products from the tests will be dried and sent to PNNL for analysis.

7. Once the assays of the products are received, Knelson will perform a metallurgical balance and write a report summarizing the findings from the test work. 


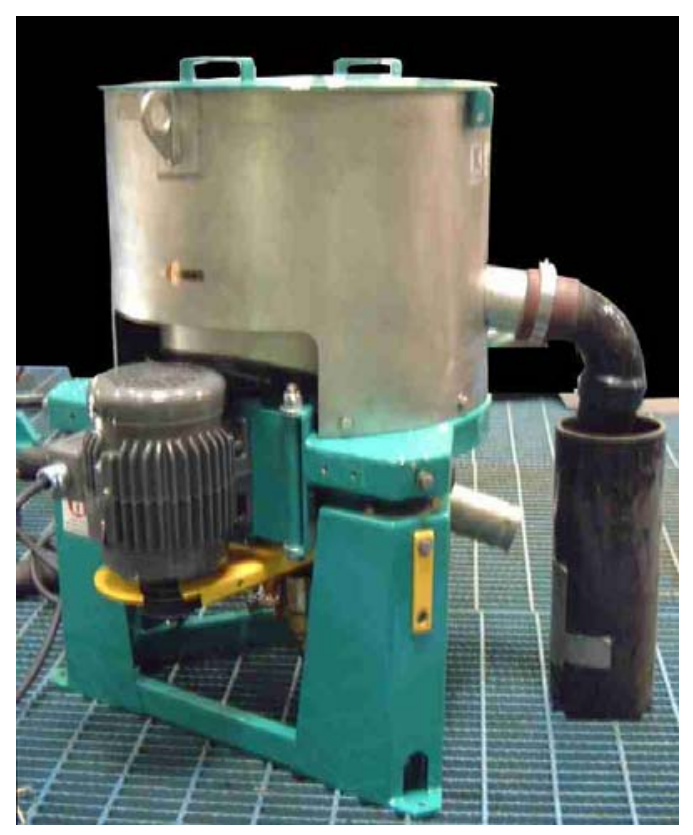

Figure 7. Knelson Pilot-Scale Continuous Variable Discharge Concentrator (CVD-6) with a 0.6 to 2.2 ton/hr (Solids) Feed Capacity

\subsection{References}

Duncan, D. R. 2001. Spent Nuclear Fuel Project Technical Databook, Volume 1, Fuel, HNF-SD-SNFTI-015, Revision 7, Fluor Hanford, Richland, WA.

Mellinger, G. B., C. H. Delegard, M. A. Gerber, B. N. Naft, A. J. Schmidt, T. L. Walton. 2004. Disposition Options for Hanford Site K Basin Spent Nuclear Fuel Sludge.” PNNL-14729, Pacific Northwest National Laboratory, Richland, WA.

Plys, M. G., and A. J. Schmidt. 2003. Supporting Basis for Spent Nuclear Fuel Project Sludge Technical Databook. SNF-7765, Rev. 2, Fluor Hanford, Richland, WA.

Schmidt, A. J., and M. R. Elmore. 2002. Settling Test Using Simulants to Evaluate Uranium Metal Distribution in K Basin Sludge. PNNL-13854, Pacific Northwest National Laboratory, Richland, WA.

Weiss, N. L. 1985. SME Mineral Processing Handbook, Vol 1. Society of Mining Engineers, of the American Institute of Mining Metallurgical and Petroleum Engineers, Inc., NY. 


\section{Attachment A}

\section{Conceptual K Basin Sludge U-Metal Segregation Process}




\section{Attachment A}

\section{Conceptual K Basin Sludge U-Metal Segregation Process}

This attachment provides a preconceptual flowsheet of a gravity separations process for removing and concentrating uranium metal from K Basin sludge.

Process Objective: Removal of uranium metal from the bulk of the sludge to reduce the gas generation potential of the sludge. With off-the-shelf gravity concentration technology (e.g., precious metal/gemstone recovery), perform operations to remove $90 \%$ or more of the uranium metal from the sludge (Figure A.1). The uranium metal depleted stream would be grouted and dispositioned to WIPP as RH-TRU. The metal concentrate stream would be processed to remove tramp material (e.g., uranium oxides/hydrates, aluminum hydroxide nodules, hydrogen/water- bearing constituents). If sufficiently cleaned, the resulting concentrated uranium metal stream would then be dispositioned to MCOs and dried at CVD. If the hydrogen/water-bearing content of the final concentrate stream could not be reduced to allow the stream to be dispositioned to the MCOs, another treatment process (e.g., hot water oxidation) would be required for this low-volume stream.

Process Throughput Goal: Process all K Basin sludge $\left(\sim 50 \mathrm{~m}^{3}\right)$ in 1 year or less; 1 to $5 \mathrm{~m}^{3}$ per week.

Process Location: One system on the deck of the KW Basin pool. It is also possible that the operation would be performed at the same location as the grouting operation (possibly in an empty bay within CVD).

Deployment Concept: Metal concentrating equipment would be skid-mounted and shielded (via portable shielding) on or near the deck of the KW pool. Feed and product tanks, and associated pumps, would be located underwater in the pool. No significant air emissions are expected for this process (i.e., no new offgas treatment requirements). [While it may be possible to operate the concentration equipment underwater, such a deployment option would require moderate process development.]

Operating mode: Batch-recycle operations. Nominally, 1 to $5 \mathrm{~m}^{3}$ batches.

\section{Metal Removal/Concentration Process Description}

Sludge mobilization and size reduction: Sludge would be mobilized and pumped to the process feed tank (Figure A.1). If needed, the feed tank would be mixed (via agitator or slurry mix pump) to maintain the sludge as a mixed slurry. The mixing intensity could potentially be set at a level that would break up large agglomerates and reduce the size of aluminum hydroxide nodules, which are highly friable. Alternatively, the sludge could be processed through a loop that would include an in-line grinder to reduce the non-metallic uranium particulate to less than $2000 \mu \mathrm{m}$. [Note: less than $10 \%$ of the KE canister and floor sludge is made up of material with a particle size greater than $2000 \mu \mathrm{m}]$. Testing would be required to determine whether a pump would be effective in breaking up larger-diameter sludge. 
U metal depletion step (primary loop): From the process feed tank, the slurry will be fed to a mineral processing pre-concentration unit operation (Figure A.1). Commercially available devices that may be applicable for this operation include a pulsed jigging device and a centrifugal concentrator.

The tails (uranium metal depleted stream) from the concentration device would be recycled back to the feed tank and then back through the device to achieve a high uranium metal removal efficiency. When the batch is completed (after $\sim 30$ to 240 min of processing), the tails would be pumped to the grout feed tank.

The concentrate stream (uranium-metal-rich stream) would be staged in a separate tank for additional processing.

U-metal concentrate cleaning (upgrading) step ( $2^{\text {nd }}$ loop), i.e., removal of tramp material: The uraniumrich concentrate steam (concentrate from U-metal depletion step) will contain some tramp material, including aluminum and iron hydroxides and some uranium oxy-hydrates, that can decompose to release water. Most of the hydroxides/hydrates will need to be removed from the concentrate stream to allow the uranium metal to be dispositioned to MCOs (temperatures in CVD are not sufficient to decompose/remove the water from the hydroxides and crystal hydrates). The unit operation(s) for refining/cleaning the concentrates is currently not defined; however, a commercial centrifugal concentrator could potentially be used. For this operation, the feed stream from the concentrated feed tank (Figure A.1) would be recycled through a concentrate cleaner.

The concentrated metal stream from this operation would be loaded into a container for eventual drying in an MCO. The tails from this process would be recycled back to the process feed tank. 


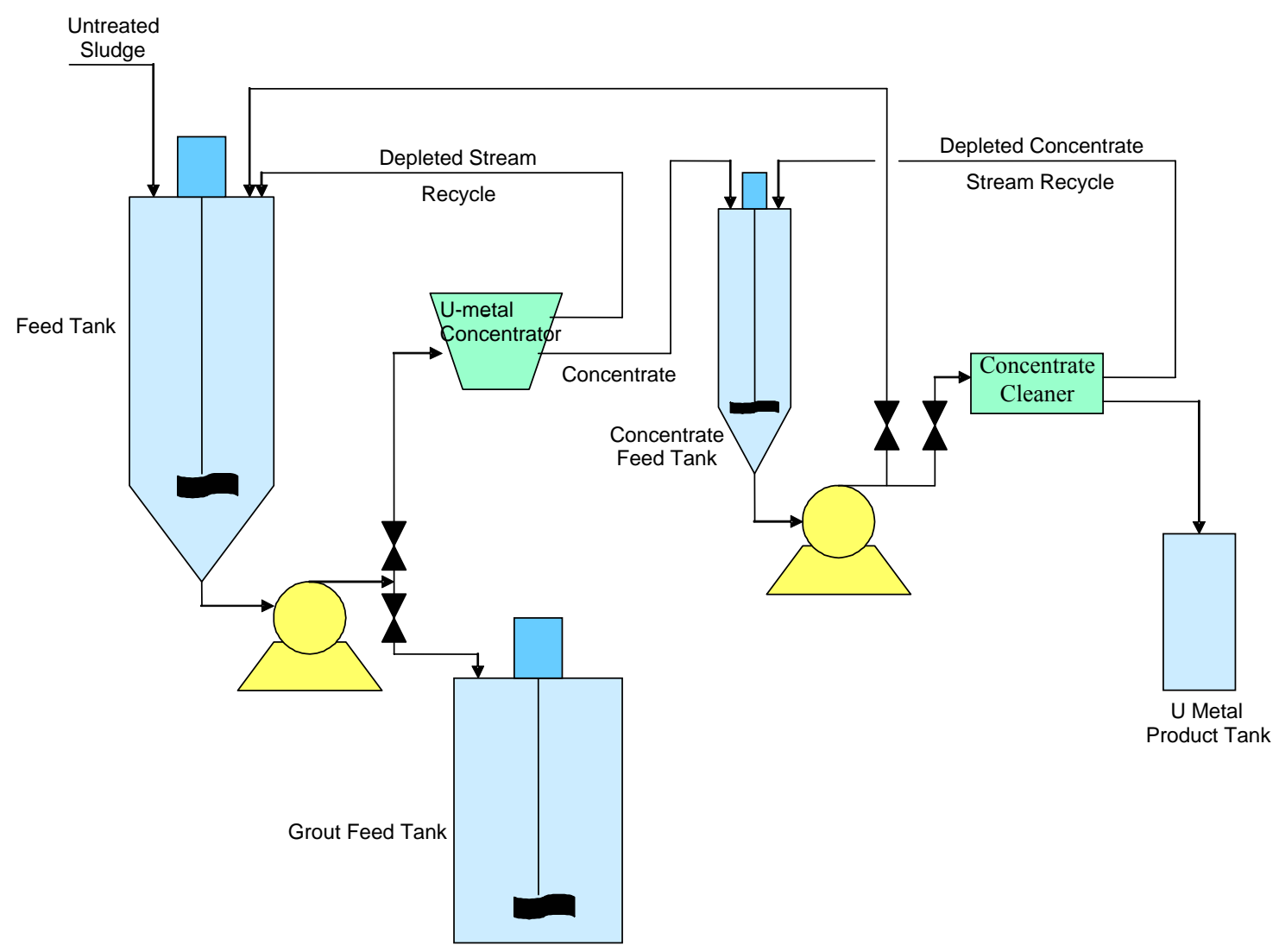

Figure A.1. Process Flow Diagram for Conceptual K Basin Sludge Uranium Metal Segregation 


\section{Attachment B}

Uranium Metal Segregation Simulant Composition 


\section{Attachment B}

\section{Uranium Metal Segregation Simulant Composition}

In earlier simulant-based work, i.e., KE Basin sludge settling test (Schmidt and Elmore 2002), a simulant resembling a 40/60 canister/floor sludge (safety basis) was developed. This settling simulant was based in part on the $\mathrm{K}$ Basin simulant developed for the large diameter container (LDC) proof-of-principle (PoP) test. ${ }^{\text {(a) }}$ The PoP simulant was composed of $8 \mathrm{wt} \% \mathrm{~W} / \mathrm{Co}, 17 \mathrm{wt} \%$ flyash (typically between 0.5 and $180 \mu \mathrm{m}$ ), 37.5\% Min-U-Sil-40 (a ground silica, with majority of particles between 5 and $20 \mu \mathrm{m}$ ), and $37.5 \%$ foundry sand (majority of particles between 100 and $400 \mu \mathrm{m}$ ). The particle size distribution (PSD) and settling behavior of the PoP simulant were found to be very similar to that of KE Basin floor sludge and was keyed off simulants/in-basin experience related to successful $\mathrm{K}$ Basin sludge sampling equipment developed and applied since 1995. The yield strength of the K Basin PoP simulant was found to be $93 \mathrm{~Pa}$ after 24 hours, and $106 \mathrm{~Pa}$ after 48 hours, which correlates well with values found for samples of actual floor and canister sludges. In the segregation sludge simulant, the foundry sand has been replaced by Kleen Blast, a material produced from copper smelting slag.

W/Co to simulate metallic uranium: KENFCEXP; $-1500 \mu \mathrm{m}+250 \mu \mathrm{m}(60 \mathrm{mesh})$, hereafter referred to as $\mathrm{W} / \mathrm{Co}$, having a composition of $6.9 \% \mathrm{Co}, 5.7 \% \mathrm{C}, 0.05 \mathrm{wt} \% \mathrm{Ti}$; balance $(87 \%)$ is $\mathrm{W}$. Particle density of $\mathrm{W} / \mathrm{Co}$ is $\sim 14.5 \mathrm{~g} / \mathrm{cm}^{3}$; bulk dry density, $\sim 10 \mathrm{~g} / \mathrm{cm}^{3}$. Particles range from 250 to $1500 \mu \mathrm{m}$, with an average particle size of $\sim 580 \mu \mathrm{m}(50 \%-1500 \mu \mathrm{m},+580 \mu \mathrm{m} ; 50 \%-580 \mu \mathrm{m},+250 \mu \mathrm{m})$. It is expected that most of the uranium fragments in actual K Basin sludge will be between 250 and $2000 \mu \mathrm{m}$. [Note: Schmidt and Elmore (2002) used W/Co that exhibited a slightly different PSD.]

Stainless steel particles to simulate non-metallic uranium: During corrosion of uranium metal in water, $\mathrm{UO}_{2}$ particles on the order $10 \mu \mathrm{m}$ and smaller are generated. During storage, the $\mathrm{UO}_{2}$ will further react to form other uranium oxides and hydrates with a range of particle densities between about 5 and $11 \mathrm{~g} / \mathrm{cm}^{3}$. Based on analyses developed in Schmidt and Delegard (2002), the average particle density of the nonmetallic uranium species in floor and canister sludge is estimated to be about $7.5 \mathrm{~g} / \mathrm{cm}^{3}$. Therefore, a suitable surrogate for the non-metallic uranium would be stainless steel powder $\left(\sim 7.8 \mathrm{~g} / \mathrm{cm}^{3}\right)$. A stainless steel powder in which all particles are less than $125 \mu \mathrm{m}$, and 38 to $48 \%$ are less than $44 \mu \mathrm{m}$ will be used.

[Note: It is recognized that while the majority of the non-metallic uranium particles are less than $250 \mu \mathrm{m}$, non-metallic uranium particles/fragments/agglomerates larger than $250 \mu \mathrm{m}$ are present in K Basin sludge samples. As an example, about $40 \mathrm{wt} \%$ (dry basis) of KE canister sludge sample 96-06 was made up of particles greater than $710 \mu \mathrm{m}$ (Makenas et al. 1997). On a dry weight basis, the uranium content of 96-06 was about $83 \%$, which would indicate the larger-diameter (greater than $700 \mu \mathrm{m}$ ) particles contained an appreciable quantity of uranium. Use of the stainless steel powder to simulate the non-metallic uranium simplifies the simulant.]

Fragments to simulate larger-diameter "inert" sludge particles: Approximately $25 \mathrm{wt} \%$ of the actual KE floor and canister sludge is made of particles greater than $500 \mu \mathrm{m}$. For actual K Basin sludge, very

(a) Baker, R. B., and A. J. Schmidt. November 20, 2001. "Summary Recommendations for Sampling to Support Proof of Principle Testing of the Sludge Transport System Large Container.” Letter to G. A. Sly, 01-SNF/RBB006, Spent Nuclear Fuel Project, Fluor Hanford, Richland, WA.

B. 1 
limited data exist on particle density as a function of particle size (Bredt et al. 1999). For canister sludge, particles between 500 and $1410 \mu \mathrm{m}$ exhibited a density of $4.63 \mathrm{~g} / \mathrm{cm}^{3}$. The particle densities of larger canister sludge particles were $2.89 \mathrm{~g} / \mathrm{cm}^{3}(1410$ to $4000 \mu \mathrm{m})$ and $2.23 \mathrm{~g} / \mathrm{cm}^{3}$ (4000 to $\left.6350 \mu \mathrm{m}\right)$. For floor sludge, the particle densities were $3.14 \mathrm{~g} / \mathrm{cm}^{3}(<250 \mu \mathrm{m}), 2.78 \mathrm{~g} / \mathrm{cm}^{3}$ (250 to $\left.500 \mu \mathrm{m}\right)$, and $2.63 \mathrm{~g} / \mathrm{cm}^{3}$ (500 to $\left.1410 \mu \mathrm{m}\right)$.

In comparison, the particle densities of agate, basalt, and silica are $2.6,2.7$, and $2.1 \mathrm{~g} / \mathrm{cm}^{3}$, respectively. Given that the particle density of W/Co is 76\% (i.e., 14.5/19) of that of metallic uranium, then agate, basalt, or silica fragments should be a suitable surrogate for the large-particle inert material found in the $\mathrm{K}$ Basin sludge. A sand blasting product, Kleen Blast, sold in a range of size distributions, including $-6+8$ mesh, $-8+12$ mesh, and -16+30 mesh, has been used to simulate the larger-diameter inert particles. Kleen Blast is roughly composed of $45 \%$ silicon, $23 \mathrm{wt} \%$ iron oxide, $19 \%$ calcium oxide, and $7 \%$ aluminum, and its particle density is approximately $2.8 \mathrm{~g} / \mathrm{cm}^{3}$. It is recognized that the use of a single component to simulate all large non-metallic uranium particles is a simplification of the complex composition of the actual K Basin sludge.

Table B.1 summarizes the simulant composition and provides the component particle densities and component particle size distributions. Figure B.1 compares the target PSDs of the simulant to the average PSDs from actual KE floor and canister samples (Schmidt 2004). The Spent Nuclear Fuel/Sludge Project definition of sludge is any particulate material that will pass through a screen with $1 / 4-i n .(6350-\mu \mathrm{m})$ openings. In sludge samples from the K Basins, the amount of particles between 4000 and $6350 \mu \mathrm{m}$ has been found to be relatively small (e.g., 0 to 4\%, Schmidt 2004)-given this, the current uranium metal segregation simulant was developed to provide a reasonably challenging case, with its range of particles being no greater than $4000 \mu \mathrm{m}$.

Table B.1. Metal Segregation Simulant Composition and Properties

\begin{tabular}{|c|c|c|c|c|c|c|c|c|c|}
\hline & W/Co & $\begin{array}{c}\text { SS } \\
\text { Powder }\end{array}$ & $\begin{array}{c}\text { Kleen } \\
\text { Blast } \\
(-6+8) \\
\end{array}$ & $\begin{array}{c}\text { Kleen } \\
\text { Blast } \\
(-8+12) \\
\end{array}$ & $\begin{array}{c}\text { Kleen } \\
\text { Blast } \\
(\mathbf{- 1 6 + 3 0 )} \\
\end{array}$ & Flyash & $\begin{array}{c}\text { Min-U- } \\
\text { Sil-40 }\end{array}$ & Goethite & Simulant \\
\hline Wt Percent, dry & 3.2 & 32 & 10 & 10 & 9 & 15.4 & 15.4 & 5 & 100 \\
\hline $\begin{array}{c}\text { Particle density, } \\
\mathbf{g} / \mathbf{c m}^{3}\end{array}$ & \begin{tabular}{|c|}
$14.5-$ \\
15.0 \\
\end{tabular} & 7.8 & $2.6-2.8$ & $2.6-2.8$ & $2.6-2.8$ & $2.2-2.5$ & 2.65 & 4.03 & \\
\hline Micron & \multicolumn{9}{|c|}{ Particle Size Distribution, Wt Percent Less Than } \\
\hline 4000 & 100 & 100 & 100 & 100 & 100 & 100 & 100 & 100 & 100 \\
\hline 2380 & 100 & 100 & 74.91 & 64.61 & 99.69 & 100 & 100 & 100 & 93.9 \\
\hline 2000 & 100 & 100 & 26.10 & 38.46 & 94 & 100 & 100 & 100 & 85.9 \\
\hline 1500 & 100 & 100 & 10 & 8 & 50 & 100 & 100 & 100 & 77.3 \\
\hline 1000 & 83 & 100 & 0.5 & 5 & 40 & 100 & 100 & 100 & 74.6 \\
\hline 750 & 65.7 & 100 & 0 & 2 & 20 & 100 & 100 & 100 & 71.9 \\
\hline 500 & 21.6 & 100 & 0 & 0.5 & 10 & 100 & 100 & 100 & 69.4 \\
\hline 250 & 0.41 & 100 & 0 & 0 & 1.69 & 100 & 100 & 100 & 68 \\
\hline 106 & 0 & 83.6 & 0 & 0 & 0.5 & 97.8 & 100 & 100 & 62.3 \\
\hline 100 & 0 & 80.7 & 0 & 0 & 0 & 97.4 & 100 & 100 & 61.2 \\
\hline 53 & 0 & 39.5 & 0 & 0 & 0 & 88 & 98 & 100 & 46.3 \\
\hline 30 & 0 & 17.3 & 0 & 0 & 0 & 75 & 94 & 100 & 36.5 \\
\hline 20 & 0 & 7.8 & 0 & 0 & 0 & 65 & 83 & 100 & 30.3 \\
\hline 10 & 0 & 1.3 & 0 & 0 & 0 & 45.6 & 46 & 100 & 19.5 \\
\hline 5 & 0 & 0 & 0 & 0 & 0 & 30 & 26 & 100 & 13.6 \\
\hline 1 & 0 & 0 & 0 & 0 & 0 & 7.8 & 7 & 98.4 & 7.2 \\
\hline
\end{tabular}




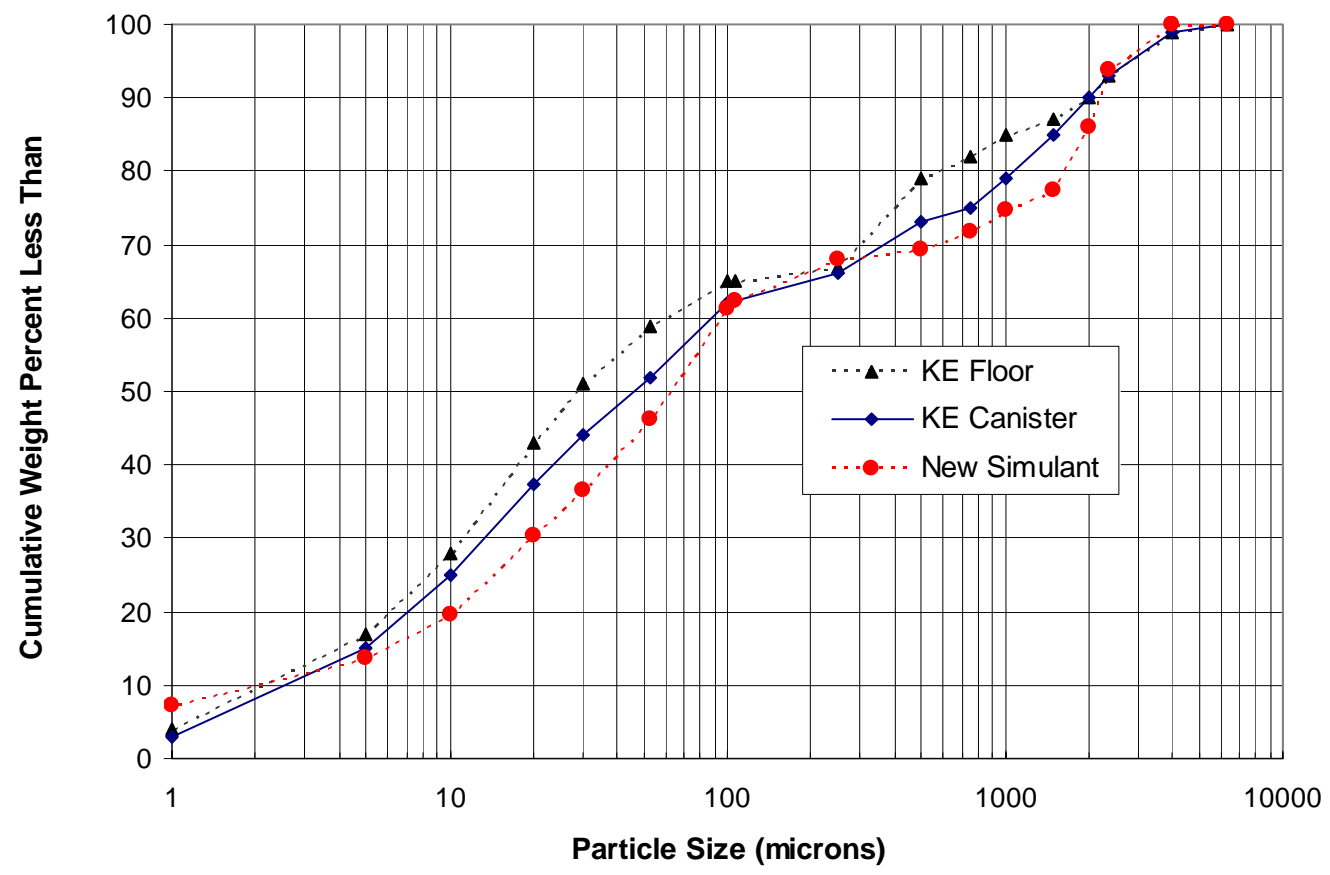

Figure B.1. Comparison of the Particle Size Distributions of the Uranium Segregation Simulant (New Simulant) to Average PSD of KE Floor and Canister Sludge Samples

\section{References}

Bredt, P. R., C. H. Delegard, A. J. Schmidt, and K. L. Silvers. 1999. Testing and Analysis of Consolidated Sludge Sample from 105K East Basin Floor and Canisters. PNNL-13341, Pacific Northwest National Laboratory, Richland, WA.

Makenas, B. J., T. L. Welsh, R. B. Baker, E. W. Hoppe, A. J. Schmidt, J. Abrefah, J. M. Tingey, P. R. Bredt, and G. R. Golcar. 1997. Analysis of Sludge from Hanford K East Basin Canisters. HNF-SP-1201, DE\&S Hanford, Inc., Richland, WA.

Schmidt, A. J. 2004. Spent Nuclear Fuel Project Technical Databook, Volume 2, Sludge. HNF-SD-TI015, Rev. 11, Fluor Hanford, Richland, WA.

Schmidt, A. J., and C. H. Delegard. 2002. Assessment of K Basin Sludge Volume Expansion Resulting from Uranium Corrosion During Storage. PNNL-13786, Pacific Northwest National Laboratory, Richland, WA.

Schmidt, A. J., and M. R. Elmore. 2002. Settling Test Using Simulants to Evaluate Uranium Metal Distribution in K Basin Sludge. PNNL-13854, Pacific Northwest National Laboratory, Richland, WA. 